\title{
THE FOURTH HORSEMAN OF 21ST CENTURY: COVID-19 PANDEMIC
}

\author{
İnci Kadribey, Fatih Erkan Akay
}

Trakya University School of Medicine, Edirne, TURKEY

\begin{abstract}
As the end of 2020 is approaching, its finest message to all of us has been how a pernicious virus like Sars-CoV-2 can change the pace of the world, by being an impetus to a global pandemic. COVID-19 was declared a pandemic by WHO on March 11, 2020. Since then, it has infected more than 40 million and killed at least 1.1 million people as this review was written (October 2020). However, the 2020's come not only with challenges, such as the pandemic itself, but also with opportunities for possible breakthroughs. Throughout human history, physicians examined their patients by touching them, arranged appropriate treatments by diagnosing them applying both usual and unusual methods, and tried their best to protect public health, in some cases even by testing the drugs and vaccines they discovered on themselves first. Bedside medicine to hospital medicine, followed by laboratory medicine, are the three crucial cornerstones accepted in the medical history. We now face a fourth potential cornerstone-to-be: could the telecommunication of physicians with their patients through the internet become the fourth essential cornerstone in the history of medicine? Keywords: Covid-19, Sars-Cov-2, pandemic, healthcare
\end{abstract}

\section{INTRODUCTION}

Deadly epidemics have changed and rewritten world history, not just today, but for centuries. The pale horsemen, which is the fourth of the white, red and black horsemen of the apocalypse, and its rider symbolizes the death and epidemic disease. The Fourth Horsemen representing the pandemics such as plague, syphilis, malaria, smallpox, and HIV/AIDS that have tyrannized the word until today, is in continuity with COVID-19. As history has painfully taught us, that our journey on the world stage is temporary whereas theirs is everlasting.

Scientifically described, pandemic is the spread of infectious diseases in a transcontinental area, a term first used in 1666 (1). With the transition to an agricultural society and domestication of animals, diseases spread from animals to humans (zoonotic) have increased in numbers and took their place in history in the form of pandemics. While plague, which killed about 34 million people, is the most well-known pandemic; the Spanish flu left a soul-shattering trace in recent history by killing at least 50 million people (2, 3). Some infectious diseases, such as Cholera, which is still ongoing in several third world countries, together with Ebola and HIV/AIDS have been increasing rapidly in recent years, incessantly causing permanent damage. On the other hand, with a grim history of causing 300 million deaths in the 20th century alone, it was announced at World Health Organization's (WHO) 33rd General Assembly on 8 May 1980 that smallpox was finally eradicated (4). Characterizing a disease as a pandemic is not only due to its widespread infectious nature; it should possess 3 characteristics reported by WHO: the disease-causing agent should be able to infect and cause danger to society, it should spread rapidly among people, and the affected should not have encountered the disease before (5). Interestingly, WHO drew attention to obesity, which has an increase in prevalence lately, by announcing it as the first non-infectious disease resulting in an epidemic (6).

Sustainability and reverence towards nature by reducing consumerism could be steps taken to prevent the epidemic of not only today but the future as well, which will lift a huge weight off of healthcare professional's shoulders, who play a critical role in the continuity of human health. 


\section{Sars-CoV-2 and COVID-19}

The changing living conditions, climate, population, trade routes, and transportation all together are among the global factors which accelerate the spread of diseases in general $(7,8)$. A new member, Sars-CoV-2, took its place along with other outbreaks we had to face at the beginning of the 21st century like HIV\&AIDS (1981-current), SARS (2003), Zika (2007), and MERS (2012) (9-12). Turning into a global danger, coronavirus disease-19 (COVID-19) was declared a pandemic by WHO on March 11, 2020. At the time of writing (October 2020), the official number of infected are approximately 40 million, with 1.1 million deaths. Claimed to first appear in a wild animal market in December 2019 in Wuhan, China, the novel member of the coronavirus family has an RNA genome. According to current scientific data, Sars-CoV-2 belongs to the family with the largest known RNA genome. It binds to ACE2 receptors on the cell surface to enter the cells, in which the virus reproduces itself continuously, turning the cell into a factory for further damage (13). It has mutated approximately 12,000 times to this date (14). Regardless of age, the most common symptoms of COVID-19, which can be fatal as well, are: high fe$\operatorname{ver}\left(37.8^{\circ} \mathrm{C}\right.$ and above), dry cough, shortness of breath, and weakness. Other symptoms like painful diarrhea, loss of sense of smell, and discoloration of the skin may be present as well. The incubation period of the virus is 2 to 14 days. It can be transmitted by droplets or be taken from surfaces contaminated with the respiratory materials of the patients through hands. The duration of the virus on surfaces varies according to the temperature and humidity of the environment. However, correct use of masks to cover the mouth and nose, frequent handwashing with soap and water, and a physical distance of at least 1.5 meters are the easiest and cheapest methods of disease prevention. The asymptomatic cases constitute the greatest cause of spread of this highly contagious disease. Although there is no known effective treatment and/or vaccine for the disease yet, the search continues with international collaborations $(15,16)$.

Outstanding messages have been given by COVID-19, the newest member of diseases that changed and reshaped the world; among with malaria, plague, smallpox, cholera, Spanish flu and HIV/AIDS. One of the notable messages was about the carbon emission, which decreased by $17 \%$ with the measures taken by April 2020, demonstrating that the human damage on the atmosphere can be undone if wanted (15). The climate change and the decrease of biodiver- sity do not only contribute to the spread of infectious diseases, but also lead to an increase of average temperatures, extinction of endengared species and melting of glacieres $(16,17)$. All these factors combined, this will presumably double the number of people facing food crises in the next 10 years and create a disproportionate gap in food distribution (18). To hinder the rapid increase of climate crisis, global measures must be taken and due to the pandemic, we now know that we are capable of such. Another urgent topic that needs to be addressed is the global ban on the illegal sales at wild animal markets, which caused the COVID-19 outbreak in the first place. Bushmeat consumption which is a signature mark for higher status and wealth became a part of luxurious living. Kept in mind that this behavior is acknowledged as a luxury today, it also hosts and accelerates the spread of disease-causing organisms transmitted from animals to humans (19-21). It has now become essential to impede wild animal trade, which is a ticking time bomb for all human health (22).

\section{FUTURE OF HEALTHCARE}

Throughout human history, physicians examined their patients by touching them, arranged appropriate treatments by using uncustomary methods to the common people, such as diagnosing them based on the color and the taste of their urine, and tried their best to protect public health, in some cases even by first testing the drugs and vaccines they discovered on themselves (23). There are three important cornerstones accepted in the history of medicine: bedside medicine, hospital medicine, followed by laboratory medicine $(24,25)$. With the given circumstances and opportunities, could medicine through the internet and telecommunication become the fourth important cornerstone? With the rapid development of the internet and technology, doctors, who have been treating their patients with their hands and observational skills for centuries, are now also trying to adapt and change the patient-physician relationship to the most efficient way, benefiting from the technological means of the modern-day. $(26,27)$. For instance, more and more doctors and patients are now benefiting from remote consultations, as people tend to prevent going to medical centers due their concern to prevent possible contact with the coronavirus (28). But only time will tell, how rooted this change will become.

At this point, it must also be stated that despite rapid changes in the patient-physician relationship, the crucial elements that will still remain as confidentiality, trust, transparency, and honesty (29). No matter how 
technology shapes medical service, doctors should seek to continue working in line with their professional oaths and ethics. Without a doubt, technology will make a difference in medical services, but the crucial step is to use it in the correct way. A further point to highlight here is that not only doctors, but also the rest of the society should have equal access to sources and the knowledge on the internet. Impeding the increasing imbalance in income would make it easier for people to access their basic rights, such as the one mentioned.

Last but not least, another issue that must be stressed amidst the global pandemic is the decrease in the living and working conditions of healthcare workers. As doctors are fighting in the front row against COVID-19, their living and working conditions keep on getting worse. Measures must be taken to prevent and reverse the decrease. Grievously, after the death of Dr. Li Venliang, first person to introduce the novel coronavirus to the world, the overall picture created by the healthcare workers passing away because of coronavirus is also increasing (27). The fight against the pandemic is not only with the doctors, but also with the state and the public, i.e. with the whole section of society.

\section{CONCLUSION}

Coronavirus disease-19 is not and will not be the last pandemic we will have to face. It reminded us that pandemics are a common problem, not only for the underdeveloped countries but for the entire human race. In order to make a contribution to control the pandemic, we should stay away from crowded environments, wash hands with soap regularly, obey the physical distance rules in the community and wear masks to cover the mouth and nose.

It should be emphasized that nature is not taking revenge, does not take revenge and will not take revenge. The coronavirus is a normal result of human greed and demand, changing the natural balance according to their own desires. As 1965 Nobel Laureate in Medicine/ Physiology Dr. André Lwoff said: "Virus is virus. Is the human race ready for The Four Horseman of the next Apocalypse?"

\section{Ethics Committee Approval: N/A}

\section{Informed Consent: N/A}

Conflict of Interest: The authors declared no conflict of interest. Author contributions: Concept: IK, FEA Supervision: IK, FEA Resources: IK, FEA Materials IK, FEA Data collection and/or processing: IK, FEA Analysis and/or Interpretation: IK, FEA Literature
Search: IK, FEA Writing Manuscript: IK, FEA Critical Review: IK, FEA

Financial disclosure: The authors declared that this study received no financial support.

Editor in chief's Note: One of the author of this article, Fatih Erkan Akay is the member of the editorial board of Turkish Medical Student Journal. However, he did not take place in any stage of the editorial decision of the manuscript. The editors who evaluated this manuscript are from other institutions.

\section{REFERENCES}

1. Moris D, Folkers GK, Anthony F. What is a pandemic? The Journal of Infectious Diseases 2009;200(7):1018-21.

2. IA Khan. Plague: The dreadful visitation occupying the human mind for centuries. Trans R Soc Trop Med Hyg 2004;98(5):270-7.

3. Glezen WP. Emerging infections: Pandemic influenza. Epidemiologic Reviews 1996;18(1):64-76.

4. C Thèves, P Biagini, E Crubézy. The rediscovery of smallpox. Clin Microbiol Infect 2014;20(3):210-8.

5. Pandemic Influenza Preparedness and Response: A WHO Guidance Document. Geneva: World Health Organization; 2009.

6. Jaacks LM, Vandevijvere S, Pan A et al. The obesity transition: Stages of the global epidemic. Lancet Diabetes Endocrinol 2019;7(3):231-40.

7. Institute of Medicine (US) Forum on Microbial Threats. Global climate change and extreme weather events: Understanding the contributions to infectious disease emergence: Workshop summary. Washington (DC) National Academies Press (US); 2008.

8. Garnett GP, Lewis JJC. The impact of population growth on the epidemiology and evolution of infectious diseases. In: Caraël M, Glynn JR, editors. HIV, Resurgent Infections and Population Change in Africa. International Studies in Population. Springer, Dordrecht; 2007:7.p. 27-41.

9. Greene WC. A history of AIDS: Looking back to see ahead. European Journal of Immunology 2007;37:94-102.

10. Anderson RM, Fraser C, Ghani AC et al. Epidemiology, transmission dynamics and control of SARS: the 2002-2003 epidemic. Philos Trans R Soc Lond B Biol Sci 2004;359(1447):1091-105.

11. Musso D, Gubler DJ. Zika virus. Clin Microbiol Rev 2016;29(3):487-524.

12. Mackay IM, Arden KE. MERS coronavirus: Diagnostics, epidemiology and transmission. Virol J 2015;12:222.

13. Li W, Moore M, Vasilieva $\mathrm{N}$ et al. Angiotensin-converting enzyme 2 is a functional receptor for the SARS coronavirus. Nature 2020;426:450-4.

14. Callaway E. The coronavirus is mutating - does it matter? Nature 2020;585:174-7.

15. de Wilde AH, Snijder EJ, Kikkert M et al. Host Factors in Coronavirus Replication. Curr Top Microbiol Immunol 2018;419:1-42.

16. Guo YR, Cao QD, Hong ZS et al. The origin, transmission and 
clinical therapies on coronavirus disease 2019 (COVID-19) outbreak - an update on the status. Mil Med Res 2020;7(1):11.

17. Le Quéré C, Jackson RB, Jones MW et al. Temporary reduction in daily global CO2 emissions during the COVID-19 forced confinement. Nat Clim Chang 2020;10:647-53.

18. Cullmann J, Dilley Maxx, Egerton P et al. 2020 State of climate services. WMO 2020:1-47.

19. Friedlingstein P, Jones MW, O'Sullivan M et al. Global Carbon Budget 2019. Earth Sys Sci Data 2019;11:1783-838.

20. Peters GP, Andrew RM, Canadell JG et al. Carbon dioxide emissions continue to grow amidst slowly emerging climate policies. Nat Clim Change 2020;10:3-6.

21. Rosen GE, Smith, KF. Summarizing the Evidence on the international trade in illegal wildlife. EcoHealth 2010;7(1):24-32.

22. Karesh WB, Cook RA, Bennett EL et al. Wildlife trade and global disease emergence. Emerg Infect Dis 2005;11(7):1000-2.

23. Berger D. A brief history of medical diagnosis and the birth of the clinical laboratory. Part 1-Ancient times through the 19th century. Med Lab Obs 1999;31(7):28-30, 32, 34-40.

24. Bettmann OL, Hench PS. A Pictorial History of Medicine. 1st ed. Charles C Thomas Pub Ltd; 1956.

25. Cunningham A, Williams P. The Laboratory Revolution in Medicine. Cambridge, Great Britain: Cambridge University Press; 1992. 26. Kvedar J, Coye MJ, Everett W. Connected health: A review of technologies and strategies to improve patient care with telemedicine and telehealth. Health Affairs 2014;33:194-9.

27. Gonçalves-Bradley DC, Maria AR, Ricci-Cabello I et al. Mobile technologies to support healthcare provider to healthcare provider communication and management of care. Cochrane Database Syst Rev 2020;8(8):1-104.

28. Hollander JE, Carr BG. Virtually perfect? telemedicine for Covid-19. N Engl J Med 2020;382:1679-81.

29. Chaet D, Clearfield R, Sabin JE et al. Ethical practice in telehealth and telemedicine. J Gen Intern Med 2017;32(10):1136-40. 